\title{
Perkembangan Berpikir Probabilistik Siswa Sekolah Dasar
}

\author{
Dwi Ivayana Sari ${ }^{1}$ *, I Ketut Budayasa ${ }^{2}$, Dwi Juniati ${ }^{3}$ \\ ${ }^{1}$ STKIP PGRI Bangkalan, Bangkalan \\ ${ }^{2,3}$ Universitas Negeri Surabaya, Surabaya \\ *E-mail: dwiivayanasari@yahoo.com
}

\begin{abstract}
ABSTRAK
Berpikir probabilistik setiap orang berbeda, karena perbedaan budaya mengakibatkan perbedaan pengetahuan probabilistik, sedangkan pengetahun probabilistik mempengaruhi pemikiran probabilistik. Perbedaan berpikir probabilistik siswa berbeda-beda tergantung pada level berpikir probabilistik siswa. Di Indonesia pertumbuhan tingkat berpikir probabilistik siswa sekolah dasar sedikit mendapat perhatian oleh para peneliti. Hal ini karena materi probabilitas dikenalkan pertama kali di tingkat SMP kelas IX. Padahal mengembangkan berpikir probabilistik siswa di tingkat dasar sangat penting sebagai pondasi untuk mempelajari probabilitas di tingkat yang lebih tinggi. Oleh sebab itu, penelitian ini bertujuan untuk mengeksplorasi pertumbuhan tingkat berpikir probabilistik siswa sekolah dasar dalam menyelesaikan tugas probabilitas standar dan tugas probabilitas eksperimen. Penelitian ini merupakan penelitian deskriptif eksploratif dengan pendekatan kualitatif. Subjek penelitian ini adalah siswa leki-laki berkemampuan tinggi dan rendah. Hasil penelitian menunjukkan bahwa Level berpikir probabilistik siswa sekolah dasar mengalami pertumbuhan setelah diberi tugas probabilitas eksperimen, terutama pada tugas ruang sampel dan probabilitas suatu kejadian. Hal ini karena eksperimen memberikan pengalaman langsung kepada siswa untuk memanipulasi bendabenda yang disediakan dalam menyelesaikan tugas probabilitas. Namun, pada tugas perbandingan probabilitas level berpikir probabilistik siswa tidak mengalami perubahan. Hasil penelitian ini dapat menjadi masukan bagi guru untuk mengajarkan probabilitas di tingkat sekolah dasar dengan memberikan tugas perbandingan probabilitas sebagai langkah awal untuk menggali berpikir probabilistik siswa, terutama pada jenis tugas pemutaran spinner.
\end{abstract}

Kata kunci: Perkembangan berpikir probabilistik, Siswa sekolah dasar

\begin{abstract}
In Indonesia, probabilistic thinking growth of primary school are not considered by researchers, because the probability was firstly introduced to students in junior high school. Whereas, development of students' probabilistic thinking at the primary level is very important as foundation for studying probability at higher levels. Therefore, this study is aimed to explore probabilistic thinking growth of primary school in solving experiment and non experiment probability tasks. The type of this research was a descriptive exploratory with a qualitative approach. The subjects were two boys; high and low math ability. The results showed that the level of students' probabilistic thinking have growth after they were given the experiment probability tasks, especially on sample space and the probability of an event tasks. This is because the experiments provided a direct experience for students to manipulate objects in solving probability tasks. However, on the probability comparison tasks, level of students' probabilistic thinking has not changed. The level of students' probabilistic thinking on this task relative is at a high level. This results is as reference to teacher. In this case to teach probability material by giving probability comparison tasks as first step to explore students' probabilistic thinking, especially by using spinner.
\end{abstract}


Keywords: Probabilistic Thinking Growth, Primary School Students

\section{Pendahuluan}

Probabilitas bukan lagi hal yang asing di dunia ini. Banyak sekali kata-kata yang sering kita temui dalam kehidupan sehari-hari dengan maksud sama dengan probabilitas, seperti kemungkinan, kesempatan, peluang dan sebagainya. Kata-kata tersebut digunakan untuk mengungkapkan masalah yang bersifat probabilistik. Masalah/situasi yang bersifat probabilistik adalah masalah/situasi yang memuat unsur ketidakpasatian. Lebih lanjut [1] menjelaskan bahwa masalah/situasi yang memuat unsur ketidakpastian mengacu pada suatu kegiatan atau percobaan acak dimana terdapat beberapa hasil yang mungkin; yaitu, hasil yang sebenarnya sebelumnya tidak dapat ditentukan secara tepat.

Aktivitas mental seseorang dalam menanggapi atau menyelesaikan masalah/situasi yang memuat unsur ketidakpastian disebut dengan berpikir probabilistik. Berpikir probabilistik setiap orang berbeda. [2] dan [3] menjelaskan bahwa budaya (yang meliputi bahasa, agama dan pengalaman) mempengaruhi pengetahuan probabilistik siswa. Artinya bahwa budaya yang berbeda mengakibatkan pengetahuan probabilistik siswa juga berbeda. Pengetahuan probabilistik siswa (yang meliputi konsep-konsep informal, intuisi, heuristic) berpengaruh terhadap berpikir probabilistik siswa. Artinya bahwa pengetahuan probabilistik siswa yang berbeda mengakibatkan pemikiran probabilistik berbeda pula. Hal inilah yang menyebabkan tingkatan berpikir seseorang juga berbeda.

Berbicara mengenai tingkatan berpikir probabilistik siswa, [4] membuat kerangka kerja untuk menilai tingkat berpikir probabilistik, dengan mengajukan empat level atau empat tingkat berpikir probabilistik. Level 1 dihubungkan dengan berpikir non kuantitatif atau berpikir subjective. Level 2 dipandang sebagai transisi antara berpikir subjective dan berpikir kuantitatif yang alami (naive quantitative). Level 3 berkaitan dengan berpikir kuantitatif secara informal. Level 4 memasukkan penalaran secara numerik (numerical). [4] dalam mengembangkan level berpikir probabilistik berdasarkan pada strategi yang digunakan siswa dalam merespon tugas probabilitas.

Berkaitan dengan strategi yagn digunakan siswa dalam merespon tugas probabilitas, hasil penelitian [5] menyatakan bahwa terdapat 3 strategi yang dapat digunakan siswa yaitu numerator, denumerator dan interaksi antara numerator dan denumerator. Lebih lanjut [6] juga menyatakan bahwa terdapat 3 strategi yaitu strategi satu dimensi (OD), strategi selisih (DIF) dan strategi proporsional (PRO). Pada strategi satu dimensi dibagi menjadi 2 berdasarkan pada tugas yang diberikan, yaitu memeriksa target kejadian lebih banyak (W) dan memeriksa non target kejadian lebih sedkit (L). Pada tugas ruang sampel [7] menyatakan bahwa terdapat 6 strategi yang dapat digunakan siswa yaitu mulai dari pemilihan secara acak suatu item tanpa pengembalian item yagn tidak sesuai sampai penggunaan pola odometer dalam memilih item. Dan direvisi kembali oleh [8] menjadi 5 strategi yaitu strategi trial dan error, strategi emerging, strategi dengan pola siklik, strategi odometer dengan kesalahan dan strategi odometer.

Penelitian yang dilakukan oleh [9] terhadap dua belas siswa dari kelas 4 dan 5 sekolah dasar di Lesotho, Afrika selatan, merancang dan melaksanakan serta menilai 2 versi pengajaran eksperimen untuk menelusuri pertumbuhan berpikir probabilsitik siswa; siswa dalam versi 1 difokuskan pada analisis data eksperimen sampel kecil dan komposisi ruang sampel sebagai strategi untuk mengatasi masalah probabilitas. Sebaliknya, siswa di versi 2 ditantang untuk membuat hubungan antara data percobaan dengan sampel besar (diambil dari simulasi komputer) dan komposisi ruang sampel setelah melihat data sampel kecil dan ruang sampel simetri. Hasil penelitian ini adalah tidak ada perbedaan yang signifikan pada tingkat 
berpikir probabilistik siswa yang mengikuti setiap versi percobaan mengajar, analisis data kuantitatif dan kualitatif menunjukkan bahwa setiap versi memiliki dampak yang nyata pada pertumbuhan siswa dalam berpikir probabilistik.

Di Indonesia pertumbuhan tingkat berpikir probabilistik siswa sekolah dasar sedikit mendapat perhatian oleh para peneliti. Hal ini karena materi probabilitas dikenalkan pertama kali di tingkat SMP kelas IX. Padahal mengembangkan berpikir probabilistik siswa di tingkat dasar sangat penting sebagai pondasi untuk mempelajari probabilitas si tingkat yang lebih tinggi. Oleh sebab itu, penelitian ini bertujuan untuk mengeksplorasi pertumbuhan tingkat berpikir probabilistik siswa sekolah dasar dalam menyelesaikan tugas probabilitas standar dan tugas probabilitas eksperimen. Pemilihan tugas probabilitas standar dan tugas probabilitas eksperimen, dikarenakan berdasarkan hasil survey awal yang dilakukan oleh peneliti menghasilkan bahwa terdapat respon yang berbeda pada seorang siswa sekolah dasar kelas 5 dalam menanggapi tugas probabilitas standar dan tugas probabilitas eksperimen. Perbedaan respon ini akan berakibat pada perbedaan tingkat berpikir probabilistik setiap siswa sekolah dasar.

\section{Metode}

Subjek dalam penelitian ini adalah dua siswa laki-laki kelas 5 dengan kemampuan matematika berbeda. Pemilihan siswa laki-laki karena menurut hasil penelitian [10] dan [11] menunjukkan bahwa laki-laki memiliki nilai yang lebih tinggi dibandingkan ssiwa perempuan pada penalaran probabilsitik.

Instrumen dalam penelitian ini adalah lembar tugas probabilitas yang mengandung ruang sampel, probabilitas suatu kejadian dan perbandingan probabilitas. Sedangkan probabilitas bersyarat tidak dimasukkan pada lembar tugas probabilitas karena menurut karena menurut Moore (dalam [12]) probabilitas bersyarat, independence dan konsep random sampling dan distribusi merupakan konsep probabilitas tingkat menengah. Sedangkan subjek dalam penelitian ini adalah siswa sekolah dasar.

Ruang sampel berhubungan dengan mendaftar atau mengidentifikasi himpunan lengkap hasil yang mungkin dari masalah satu dimensi dan dua dimensi. Probabilitas dari suatu peristiwa berkaitan dengan mengidentifikasi dan memberikan alasan mana yang paling mungkin atau paling tidak mungkin terjadi. Perbandingan probabilitas berkaitan dengan menentukan dan membenarkan: (1) situasi di mana probabilitas yang paling untuk menghasilkan peristiwa sasaran; atau (2) apakah dua situasi probabilitas menawarkan kesempatan yang sama untuk acara sasaran. Soal dalam lembar tugas probabilitas dapat dilihat pada Tabel I.

Penelitian ini merupakan penelitian deskriptif eksploratif dengan pendekatan kualitatif. Sehingga peneliti sendiri yang mengumpulkan dan menganalisis data [13]. Pengumpulan data dilakukan 2 kali: (1) peneliti memberikan lembar tugas probabilitas kepada subjek. Subjek menyelesaikan tugas tersebut berdasarkan kemampuannya dan menuliskan jawaban di lembar jawaban yang telah disediakan. Kemudian peneliti menginterview subjek berkaitan dengan berpikir probabilistik siswa. Triangulasi waktu digunakan untuk memperoleh data kredibel, (2) Selanjutnya peneliti memberikan lembar tugas probabiltias, namun peneliti menyediakan bahan-bahan eksperimen dan meminta subjek untuk melakukan beberapa eksperimen sebelum subjek menuliskan jawabannya. Setelah subjek menuliskan jawaban di lembar jawaban, peneliti menginterview subjek berkaitan dengan berpikir probabilistik siswa. Triangulasi waktu digunakan untuk memperoleh data kredibel.

Selanjutnya data yang diperoleh dianalisis, dikategori, direduksi dan diinterpretasi untuk membuat kesimpulan. Dengan demikian, diperoleh tingkat berpikir probabilistik siswa sekolah dasar pada tiga masalah probabilitas, yaitu ruang sampel, probabilitas suatu kejadian 
dan perbandingan probabilitas, baik pada masalah standar maupun masalah yang memfasilitasi siswa untuk melakukan eksperimen.

TABEL 1. Masalah pada Tugas Probabilitas

\begin{tabular}{|c|c|c|}
\hline Ruagn sampel & $\begin{array}{c}\text { Probabilitas suatu } \\
\text { kejadian }\end{array}$ & Perbandingan probabilitas \\
\hline $\begin{array}{l}\text { Disediakan sebuah kotak berisi } \\
\text { bola dengan jenis dan ukuran } \\
\text { yang sama. Bola tersebut adalah } 5 \\
\text { bola kuning, } 4 \text { bola ungu dan } 3 \\
\text { bola biru. Jika kamu diminta } \\
\text { mengambil satu bola dari dalam } \\
\text { kotak dengan menutup mata, } \\
\text { maka bola warna apa saja yang } \\
\text { bisa terambil? Berikan alasanmu! }\end{array}$ & $\begin{array}{l}\text { Disediakan } r \text { sebuah } \\
\text { kotak berisi bola } \\
\text { dengan jenis dan } \\
\text { ukuran yang sama. } \\
\text { Bola tersebut adalah } 5 \\
\text { bola kuning, } 4 \text { bola } \\
\text { ungu dan } 3 \text { bola biru. } \\
\text { Jika kamu diminta } \\
\text { mengambil satu bola } \\
\text { dari dalam kotak } \\
\text { dengan menutup mata, } \\
\text { maka Bola warna apa } \\
\text { yang paling mungkin } \\
\text { terambil? Berikan } \\
\text { alasanmu! }\end{array}$ & $\begin{array}{l}\text { Disediakan } 2 \text { kotak berisi } \\
\text { spidol dengan jenis dan ukuran } \\
\text { yang sama. Kotak I berisi } 1 \\
\text { spidol hijau dan } 3 \text { spidol biru. } \\
\text { Kotak II berisi } 2 \text { spidol hijau } \\
\text { dan } 4 \text { spidol biru. Kamu } \\
\text { diminta mengambil satu spidol } \\
\text { dari dalam kotak dengan mata } \\
\text { tertutup. Jika kamu ingin } \\
\text { mendapatkan spidol berwarna } \\
\text { biru, maka sebaiknya kamu } \\
\text { mengambil spidol dari kotak } \\
\text { mana? Berikan alasanmu } \\
\text { dengan menggunakan } \\
\text { bilangan! }\end{array}$ \\
\hline $\begin{array}{l}\text { Disediakan } 2 \text { spinner masing- } \\
\text { masing dilengkapi dengan panah } \\
\text { di atasnya seperti pada gambar di } \\
\text { bawah. }\end{array}$ & $\begin{array}{l}\text { Disediakan } 1 \text { dadu. } \\
\text { Jika dadu tersebut } \\
\text { dilambungkan ke atas, } \\
\text { kemudian pada saat }\end{array}$ & $\begin{array}{l}\text { Disediakan } 2 \text { spinner masing- } \\
\text { masing dilengkapi dengan } \\
\text { panah di atasnya seperti pada } \\
\text { gambar di bawah. }\end{array}$ \\
\hline $\begin{array}{l}\text { Jika kedua spinner diputar secara } \\
\text { bersama-sama kemudian pada } \\
\text { saat kedua spinner berhenti, kamu } \\
\text { diminta untuk mengamati angka } \\
\text { dan warna yang ditunjuk oleh } \\
\text { kedua panah pada masing-masing } \\
\text { spinner, maka pasangan angka } \\
\text { dan warna apa saja yang bisa } \\
\text { ditunjuk oleh kedua panah? } \\
\text { Berikan alasanmu! } \\
\text { Disediakan } 1 \text { dadu. Jika dadu } \\
\text { tersebut dilambungkan ke atas, } \\
\text { kemudian pada saat dadu jatuh ke } \\
\text { lantai, kamu diminta untuk } \\
\text { mengamati banyak mata dadu } \\
\text { yang berada di bagian atas, maka } \\
\text { banyak mata dadu berapa saja } \\
\text { yang bisa muncul? }\end{array}$ & $\begin{array}{l}\text { terkecil untuk muncul, } \\
\text { banyak mata dadu } \\
\text { kurang dari } 4 \text { atau } \\
\text { lebih dari } 4 \text { ? Berikan } \\
\text { alasanmu! }\end{array}$ & $\begin{array}{l}\text { A } \\
\text { Jika spinner tersebut diputar } \\
\text { kemudian pada saat spinner } \\
\text { berhenti, kamu diminta untuk } \\
\text { mengamati warna yang } \\
\text { ditunjuk oleh panah pada } \\
\text { spinner, maka spinner } \\
\text { manakah yang memberikan } \\
\text { kesempatan sama bagi warna } \\
\text { biru dan merah untuk ditunjuk } \\
\text { oleh panah? Berikan alasanmu } \\
\text { dengan menggunakan } \\
\text { bilangan! }\end{array}$ \\
\hline
\end{tabular}

\section{Hasil dan Pembahasan}




\subsection{Level berpikir probabilistik siswa berkemampuan matematika tinggi pada tugas probabilitas standar}

Pada tugas ruang sampel 1 dimensi standar, siswa dapat mendaftar semua warna bola yang bisa terambil dari dalam kotak yang berisi 5 bola kuning, 4 bola ungu dan 3 bola biru. Begitu pula pada tugas pelemparan dadu, siswa dapat mendaftar banyak mata dadu 1, 2, 3, 4, 5, 6 yang bisa muncul. Namun, pada tugas ruang sampel 2 dimensi, siswa merespon bahwa semua yang ada di spinner dapat ditunjuk oleh jarum, namun siswa tidak memasangkan angka dan warna yang bisa ditunjuk. Dengan demikian, pada tugas ruang sampel level berpikir probabilistik siswa berkemampuan tinggi berada pada level 2 yaitu level transisi, karena siswa dapat mendaftar secara lengkap hasil yang mungkin untuk tugas ruang sampel 1 dimensi, namun untuk tugas ruang sampel 2 dimensi tidak mendaftar pasangan angka dan warna yang bisa ditunjuk.

Pada tugas probabilitas suatu kejadian standar, siswa merespon bahwa bola yang paling mungkin terambil dari dalam kotak yang berisi 5 bola kuning, 4 bola ungu dan 3 bola biru adalah bola berwarna kuning karena jumlah bola berwarna merah paling banyak daripada bola warna yang lain. Selanjutnya siswa merepon bahwa banyak mata dadu kurang dari 4 yang memiliki kesempatan terkecil untuk muncul jika dadu dilempar ke atas dan diamati banyak mata dadu yang muncul di atas permukaan. Alasan siswa bahwa banyak mata dadu yang sedikit, maka keberuntungannya juga kecil. Ini menunjukkan bahwa respon siswa mengacu pada penalaran subjektif. Sehingga berpikir probabilistik pada tugas probabilitas suatu kejadian ini berada pada level 2 (transisi), karena respon siswa berdasarkan pada alasan kuantitatif, tetapi pada tugas dadu respon siswa berdasarkan alasan subjektif.

Pada tugas perbandingan probabilitas standar, berpikir probabilsitik siswa berada pada level 4 (numerik) karena siswa memberikan penjelasan atas jawabannya dengan menggunakan bilangan pecahan yang menunjukkan pengukuran probabilitas. Sebagai contoh, siswa merespon bahwa untuk mendapatkan spidol biru, siswa memilih untuk mengambil spidol dari kotak II, dengan alasan banyaknya spidol hijau lebih sedikit daripada banyaknya spidol hijau di kotak I. Siswa menuliskan bahwa di kotak I spidol hijau 1/4 dan spidol biru 3/4, sedangkan di kotak II spidol hijau 2/6 dan spidol biru 4/6. Begitu pula pada tugas pemutaran spinner, siswa memilih spinner A yang memebrikan kesempatan sama bagi merah dan biru untuk ditunjuk panah, alasannya karena di spinner A warna biru 4/8 dan warna merah 4/8 juga.

\subsection{Level berpikir probabilistik siswa berkemampuan matematika tinggi pada tugas probabilitas standar}

Terdapat perbedaan respon setelah siswa diberi tugas probabilitas dengan melakukan eksperimen terlebih dahulu, terutama dalam menanggapi tugas ruang sampel 2 dimensi. Setelah melakukan eksperimen pemutaran dua spinner secara bersama-sama, maka siswa dapat merespon tugas ini dengan menggunakan strategi odomoter, yaitu memilih satu item warna dan dipasangkan dengan semua angka, jika sudah selesai memilih item warna yang lain dan dipasangkan dengan semua angka. Begitu seterusnya sehingga terdapat 12 pasangan. Jawaban yang ditulis oleh siswa diilustrasikan pada Gambar 1 ..

Hal ini menunjukkan bahwa level berpikir probabilistik siswa berkemampuan tinggi meningkat yaitu berada pada level 4, karena siswa dapat mendaftar dengan lengkap hasil yang mungkin dari ruang sampel 1 dimensi dan menggunakan strategi odometer dalam menyelesaikan tugas ruang sampel 2 dimensi. 


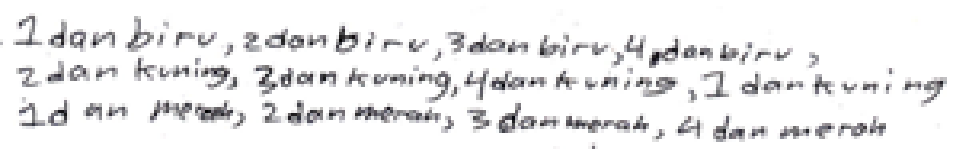

Gambar 1. Jawaban siswa pada soal no. 2

Respon siswa dalam menanggapi tugas probabilitas suatu kejadian eksperimen menyatakan bahwa banyak mata dadu yang memiliki kesempatan terkecil untuk muncul adalah lebih dari 4. Pada tugas ini siswa memeriksa banyak mata dadu kurang dari 4 dan lebih dari 4. Banyak mata dadu kurang dari 4 terdapat tiga yaitu 1, 2, 3, sedangkan banyak mata dadu lebih dari 4 terdapat dua yaitu 5 dan 6. Berdasarkan respon siswa ini menunjukkan bahwa berpikir probabilistik siswa berada pada level 3 (informal kuantitatif) karena siswa menggunakan bilangan yang menunjukkan banyaknya banyak mata dadu kurang dari 4 dan banyak mata dadu lebih dari 4, kemudian membandingkannya.

Pada tugas perbandingan probabilitas eksperimen, level berpikir probabilistik siswa tidak berubah, artinya berada pada level 4 (numerik), karena siswa memberikan penjelasan atas jawabannya dengan menggunakan bilangan pecahan yang menunjukkan pengukuran probabilitas, sama seperti respon siswa dalam menanggapi tugas probabilitas standar.

\subsection{Level berpikir probabilistik siswa berkemampuan matematika rendah pada tugas probabilitas standar}

Pada tugas probabilitas standar, siswa merespon bahwa bola kuning saja yang bisa terambil dari dalam kotak yang berisi 5 bola kuning, 4 bola ungu dan 3 bola biru. Alasannya karena bola warna kuning jumlahnya paling banyak. sedangkan pada tugas pelemparan dadu, siswa mendaftar banyak mata dadu 5 dan 6 yang muncul, karena siswa sering mendapatkan lebih dari 4 saat bermain monopoli dan ular tangga. Pada tugas ruang sampel 2 dimensi, siswa merespon bahwa pasangan angka dan warna yang bisa ditunjuk panah adalah warna biru, merah dan angka 1 dan 3, kemudian warna kuning, merah dan angka 2 dan 4. Alasan siswa adalah karena warna biru, angka 1, angka 3 berada di sebelah kiri dan warna kuning, angka 2, angka 4 berada di sebelah kanan. Sedangkan warna merah berada di tengah-tengah spinner. Jawaban siswa ini menunjukkan bahwa siswa melihat letak warna dan angka pada spinner sebelum diputar. Dan berpikir bahwa keadaan setelah diputar akan sama dengan keadaan sebelum diputar. Dengan demikian, berpikir probabilistik siswa berada pada level 1 (subjektif) karena siswa mendaftar hasil yang mungkin dari tugas ruang sampel 1 dimensi secara tidak lengkap dan berpikir secara subjektif mengenai apa yang paling mungkin terjadi daripada apa yang mungkin dan memberikan alasan berdasarkan pengalamannya dalam kehidupan sehari-hari. Begitu pula pada ruang sampel 2 dimensi, siswa berpikir secara subjektif mengenai letak angka dan warna yang sama.

Pada tugas probabilitas suatu kejadian standar, siswa merespon bahwa bola yang paling mungkin terambil dari dalam kotak yang berisi 5 bola kuning, 4 bola ungu dan 3 bola biru adalah bola berwarna kuning karena jumlah bola berwarna merah paling banyak daripada bola warna yang lain. Selanjutnya siswa merespon bahwa banyak mata dadu kurang dari 4 yang memiliki kesempatan terkecil untuk muncul jika dadu dilempar ke atas dan diamati banyak mata dadu yang muncul di atas permukaan. Alasan siswa karena setiap siswa bermain ular tangga, siswa sulit untuk mendapatkan banyak mata dadu kurang dari 4 saat akan mencapai finish. Ini menunjukkan bahwa respon siswa mengacu pada pengalamannya sehari-hari saat bermain. Sehingga berpikir probabilistik pada tugas probabilitas suatu kejadian ini berada pada level 2 (transisi), karena respon siswa berdasarkan pada alasan kuantitatif, tetapi pada tugas dadu respon siswa berdasarkan alasan subjektif.

Pada tugas perbandingan probabilitas standar, siswa merespon bahwa untuk mendapatkan spidol berwarna biru, lebih baik mengambil spidol dari kotak II, karena di kotak 
II berisi 4 spidol biru, sedangkan di kotak I berisi 3 spidol biru. Ini menunjukkan bahwa strategi yang digunakan siswa adalah lebih banyak dari target kejadian. Namun, pada tugas pemutaran spinner, siswa merespon bahwa spinner B yang memberikan kesempatan sama bagi merah dan biru untuk ditunjuk panah, karena bagian warna merah dan biru di spinner B sama-sama 50\%, sedangkan di spinner A $60 \%$ warna merah dan $40 \%$ warna biru. Ini menunjukkan bahwa berpikir probabilistik siswa berada pada level 3 karena siswa menggunakan strategi lebih dari warna spidol target dan menggunakan persentase dalam menjelaskan penalarannya pada tugas pemutaran spinner

\subsection{Level berpikir probabilistik siswa berkemampuan matematika rendah pada tugas probabilitas eksperimen}

Setelah siswa diberikan tugas probabilitas dengan eksperimen, siswa merespon bahwa semua warna bola yaitu bola berwarna kuning, ungu dan biru bisa diambil dari dalam kotak dengan mata tertutup dan semua banyak mata dadu 1, 2, 3, 4, 5, 6 juga dapat muncul. Namun, pada tugas ruang sampel 2 dimensi, siswa mendaftar pasangan angka dan warna yang bisa ditunjuk panah secara tidak lengkap, yaitu terdapat 9 pasangan yang terdiri dari 2 dan kuning, 2 dan biru, 3 dan biru, 1 dan biru, 4 dan biru, 2 dan merah, 1 dan kuning, 2 dan kuning, 4 dan kuning, 4 dan merah. Jawaban siswa ini berdasarkan pada hasil eksperimen yang dilakukan sebanyak 20 kali pemutaran. Ini menunjukkan bahwa berpikir probabilistik siswa berada pada level 2 (transisi), karena siswa dapat mendaftar lengkap hasil yang mungkin untuk ruang sampel 1 dimensi, namun strategi yang digunakan siswa tidak sistematis dalam menanggapi tugas ruang smapel 2 dimensi.

Pada tugas probabilitas suatu kejadian, siswa tetap merespon bahwa bola yang paling mungkin terambil adalah bola berwarna kuning karena jumlah bola berwarna merah paling banyak daripada bola warna yang lain. Sedangkan saat diberi tugas probabilitas suatu kejadian dengan eksperimen, respon siswa mengacu pada hasil eksperimen, yaitu banyak mata dadu kurang dari 4 yang memiliki kesempatan terkecil untuk muncul. Siswapun menambahkan respon bahwa hasil eksperimen tersebut juga sama dengan saat dia bermain dadu, yaitu sering mendapat banyak mata dadu lebih dari 4. Ini menunjukkan berpikir probabilistik siswa masih berada di level 2 (transisi).

Pada tugas perbandingan probabilitas eksperimen, respon siswa berubah yaitu untuk mendapatkan spidol berwarna biru, lebih baik mengambil spidol dari kotak I, karena di kotak I berisi 1 spidol hijau, sedangkan di kotak II berisi 2 spidol hijau. Siswa berpikir bahwa bukan banyak spidol biru yang diperhatikan, namun banyaknya spidol hijau yang diperhatikan. Jika di sebuah kotak mengandung spidol hijau lebih sedikit, maka akan mudah mendapatkan spidol biru. Ini menunjukkan bahwa strategi yang digunakan siswa adalah kurang dari nontarget kejadian. Namun, pada tugas pemutaran spinner, respon siswa tidak berubah. Siswa menjawab bahwa spinner B yang memberikan kesempatan sama bagi merah dan biru untuk ditunjuk panah, karena bagian warna merah dan biru di spinner B sama-sama 50\%, sedangkan di spinner A $60 \%$ warna merah dan $40 \%$ warna biru. Ini menunjukkan bahwa berpikir probabilistik siswa berada pada level 3 karena siswa menggunakan strategi kurang dari nontarget kejadian (memeriksa banyaknya elemen non target kejadian) dan menggunakan persentase dalam menjelaskan penalarannya pada tugas pemutaran spinner.

Berdasarkan hasil penelitian menunjukkan bahwa level berpikir siswa berkemampuan tinggi dalam menanggapi tugas ruang sampel mengalami pertumbuhan, pada tugas standar level berpikir probabilsitik siswa berada pada level 2 dan mengalamai peningkatan ke level 4 pada tugas eksperimen. Hal ini dikarenakan siswa dapat mendaftar secara lengkap hasil yang mungkin pada tugas ruang sampel 2 dimensi menggunakan strategi odometer. Begitu pula level berpikir probabilitistik 
siswa berkemampuan rendah juga mengalami pertumbuhan pada tugas ruang sampel, dari level 1 menjadi level 2 setelah diberi tugas eksperimen. Hal ini dikarenakan siswa daftar mendaftar secara lengkap hasil yang mungkin pada tugas ruang sampel 1 dimensi, namun siswa mendaftar secara tidak lengkap pada tugas ruang sampel 2 dimensi.

Pada tugas probabilitas suatu kejadian, level berpikir siswa berkemampuan tinggi juga mengalami pertumbuhan. Pada tugas standar, level berpikir probabilistik siswa berada pada level 2, karena respon siswa menunjukkan alasan kuantitatif pada tugas pengambilan bola, namun respon siswa menunjukkan alasan subjektif pada tugas pelemparan dadu, sedangkan level berpikir siswa berada pada level 3 (informal kuantitatif), karena siswa menggunakan bilangan secara informal dalam membandingkan banyak mata dadu kurang dari 4 dan lebih dari 4 . Namun, level berpikir siswa berkemampuan rendah tidak mengalami pertumbuhan setelah diberi tugas eksperimen, yaitu tetap berada pada level 2 (transisi). Hal ini karena respon siswa pada tugas pelemparan dadu eksperimen berdasarkan pada hasil eksperimen yang sesuai dengan penglamannya saat bermain. Sedangkan pada tugas pengambilan bola, respon siswa menunjukkan bahwa jumlah yang paling banyak, paling mungkin terambil.

Pada tugas perbandingan probabilitas, level berpikir siswa berkemampuan tinggi tidak mengalami perubahan saat menyelesaikan tugas standar dan tugas eksperimen yaitu berada pada level 4 (numerical), karena siswa memberikan penjelasan atas jawabannya dengan menggunakan bilangan pecahan yang menunjukkan pengukuran probabilitas. Begitu pula dengan level berpikir probabilistik siswa berkemampuan rendah tidak mengalami perubahan saat menyelesaikan tugas standar dan tugas eksperimen yaitu berada pada level 3 (informal kuantitatif), karena siswa menggunakan strategi kurang dari non-target kejadian (memeriksa banyaknya elemen non target kejadian) pada tugas pengambilan spidol dan menggunakan persentase dalam menjelaskan penalarannya pada tugas pemutaran spinner.

Berdasarkan penjelasan di atas, maka level berpikir probabilistik siswa mengalami pertumbuhan setelah diberikan tugas eksperimen, terutama pada tugas ruang sampel dan probabilitas suatu kejadian. Hal ini karena tugas eksperimen memberi penglaman langsung bagi siswa dengan memanipulasi benda-benda yang disediakan untuk menyelesaikan tugas probabiltias. Lebih lanjut [9] yang menyatakan bahwa there were no significant differences in probabilistic thinking levels of students who followed two version of the teaching experiment. Namun, pada tugas perbandingan probabilitas level berpikir probabilistik siswa tidak mengalami perubahan, karena level berpikir siswa pada tugas ini relatif berada pada level tinggi.

Pada tugas perbandingan probabilitas, siswa berkemampuan tinggi dan rendah menunjukkan level berpikir yang lumayan tinggi, yaitu level 4 (siswa berkemampuan tinggi) dan level 3 (siswa berkemampuan rendah). Dengan demikian, hasil penelitian ini dapat menjadi masukan bagi guru untuk mengajarkan probabilitas di tingkat sekolah dasar dengan memberikan tugas perbandingan probabilitas sebagai langkah awal untuk menggali berpikir probabilistik siswa. Disamping itu, penelitian ini menghasilkan bahwa pada tugas perbandingan probabilitas khususnya pada tugas pemutaran spinner, siswa berkemampuan 
tinggi menggunakan pecahan sebagai representasi berpikir probabilsitiknya dan siswa berkemampuan rendah menggunakan persentase sebagai representasi berpikir probabilsitiknya. Dengan demikian, langkah awal untuk mengajarkan konsep probabilitas kepada siswa sekolah dasar, tidak hanya melalui tugas perbandingan probabilitas, namun jenis tugas perbandingan probabilitas menggunakan jenis tugas pemutaran spinner. Hal ini karena bentuk spinner seperti lingkaran, sehingga dapat mengembangkan strategi numerik sederhana ke dalam penalaran proporsional dalam menanggapi tugas probabilitas, yaitu dengan menghubungkannya dengan materi yang telah dipelajari sebelumnya, yaitu pecahan dan diagram. Hal ini sesuai dengan pendapat [14] yang menyatakan bahwa children around the age of 9 years possess the basic probability concepts and are likely to be responsive to instruction that assists them to develop simple numerical strategies into more sophisticated proportional thinking.

\section{Simpulan}

Level berpikir probabilistik siswa sekolah dasar mengalami pertumbuhan setelah diberi tugas probabilitas eksperimen, terutama pada tugas ruang sampel dan probabilitas suatu kejadian. Hal ini karena eksperimen memberikan pengalaman langsung kepada siswa untuk memanipulasi benda-benda yang disediakan dalam menyelesaikan tugas probabilitas. Namun, pada tugas perbandingan probabilitas level berpikir probabilistik siswa tidak mengalami perubahan, karena level berpikir siswa pada tugas ini relatif berada pada level tinggi, yaitu level 4 (siswa berkemampuan tinggi) dan level 3 (siswa berkemampuan rendah). Hasil penelitian ini dapat menjadi masukan bagi guru untuk mengajarkan probabilitas di tingkat sekolah dasar dengan memberikan tugas perbandingan probabilitas sebagai langkah awal untuk menggali berpikir probabilistik siswa, terutama pada jenis tugas pemutaran spinner. Hal ini karena bentuk spinner seperti lingkaran, sehingga dapat mengembangkan strategi numerik sederhana ke dalam penalaran proporsional dalam menanggapi tugas probabilitas, yaitu dengan menghubungkannya dengan materi yang telah dipelajari sebelumnya, yaitu pecahan dan diagram.

\section{DAFTAR PUSTAKA}

[1] Jones, G. A, Langrall, C. W, Thornton, C. A, Mogill, A. T., Students' probabilistic thinking in instruction. Journal for Research in Mathematics Education. Vol. 30, No.5, (487-.519). 1999.

[2] Amir, Gilead, S., \& Williams, Julian, S. (1999). Cultural Influences on Children's Probabilistic Thinking. Journal of Mathematical Behavior, 18 (1), 85 - 107.

[3] Sharma, S. (2012). Cultural Influences in Probabilistic Thinking. Journal of Mathematics Research; Vol. 4, No. 5, ISSN 1916-9795 E-ISSN 1916-9809, doi:10.5539/jmr.v4n5p63 URL: http://dx.doi.org/10.5539/jmr.v4n5p63

[4] Jones, G. A, Langrall, C. W, Thornton, C. A, Mogill, A. T. (1997). A Framework for Assessing and Nurturing Young Children's Thinking in Probability. Educational Studies in Mathematics 32: 101-125

[5] Acredolo, C., O’Conor, J., Banks, L., Horobin, K., Children's Ability to Make Probability Estimates: Skills Revealed Through Applicaion of Anderson's Functional Measurement Methhodology. Child Development. Vol. 60, No.4, (933-945). 1989. 
[6] Falk, R \& Wilkening, F., Children's Construction of Fair Chances: Adjusting Probabilities. Developmental Psychology. Vol. 34, No. 6, (1340-1357). 1998.

[7] English, Lyn D., Young Children's Combinatoric Strategies. Educational Studies in Mathematics. Vol. 22. (451-474). 1991.

[8] English, Lyn D., Children's strategies for solving two - and three - dimensional combinatorial problems. In: Leder, Gilah C. and Forgasz, Helen J., (eds.) Stepping stones for the 21st century: Australasian mathematics education research. Sense Publishers, The Netherlands, (139-156). 2007.

[9] Polaki, Mokaeane. V., Using Instruction to Identify Key Features of Basotho Elementary Students' Growth in Probabilistic Thinking. Mathematical thinking and learning. 4:4, (285-313). DOI: 10.1207/S15327833MTL0404_01. 2002.

[10] Yenilmez, A, Sungur, S \& Tekkaya, C., Investigating Students' Logical Thinking Abilities: The Effects Of Gender And Grade Level. Hacettepe Üniversitesi Egitim Fakültesi Dergisi. Vol. 28. (219-225). 2005.

[11] Paul, Mutodi., The Nature of Misconceptions and Cognitive bstacles Faced by Secondary School Mathematics Students in Understanding Probability: A Case Study of Selected Polokwane Secondary Schools. Mediterranean Journal of Social Sciences. Vol. 5, No.8, (446-455). Doi:10.5901/mjss.2014.v5n8p446. 2014.

[12] Langrall, C.W \& Mooney, E. S., Characteristics of Elementary School Students' Probabilistic Reasoning. Dalam G. A. Jones. Exploring Probability in School Challenges for Teaching and Learning. New York: Spinger. (95-119). 2005.

[13] Creswell, J.W., Qualitative Inquiry \& Research Design: Choosing Among Five Approach 2nd Edition. London: Sage Publication. 2007

[14] Way, Jenni. (2003). The Development of Young Children's Notions of Probability. European Research in Mathematics Education III. http://www.dm.unipi.it/ didattica/CERME3/proceedings/Groups/TG5/TG5_way_cerme 3.pdf 